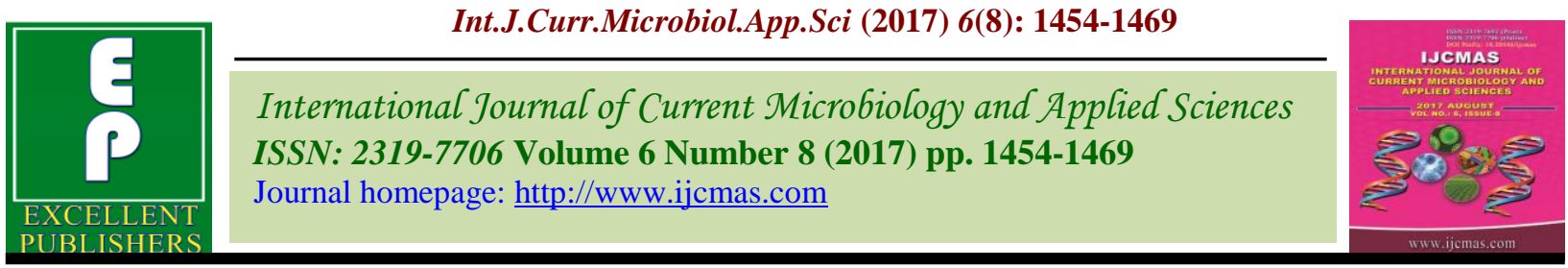

Original Research Article https://doi.org/10.20546/ijcmas.2017.608.176

\title{
Process Optimization for the Production of $\beta$-Galactosidase Using Potential Lactobacillus Cultures
}

\author{
Shrushti Makwana ${ }^{1}$, Subrota Hati ${ }^{1 *}$, Heena Parmar' ${ }^{1}$ and K. D. Aparnathi \\ ${ }^{1}$ Dairy Microbiology Department, ${ }^{2}$ DairyChemistry Department, Anand Agricultural University, \\ Anand-388110, Gujarat, India \\ *Corresponding author
}

\section{A B S T R A C T}

Ten Lactobacillus cultures were considered for the study. Out of ten Lactobacillus cultures, V3 produced maximum $\beta$-galactosidase activity (3.381 O.D), followed by NK2 and NK9 up to $24 \mathrm{~h}$ than other cultures during $\beta$-galactosidase activity. Extraction of $\beta$ galactosidase was carried out by disruption of Lactobacillus cells using sonication at 3,4 and 5 minute (pulse 30 second on / 10 seconds off and 35 to $55 \%$ amplitudes), lysozyme-

Keywords

$\beta$-galactosidase,

Lactobacillus,

Sonication, Partial purification.

Article Info

Accepted:

17 June 2017

Available Online:

10 August 2017
EDTA (49 $\mathrm{mg}$ of lysozyme in $1.5 \mathrm{ml}$ of TE buffer) treatment, toluene acetone (9:1 [toluene: acetone]) treatment, sodium dodecyl sulphate (SDS) - chloroform (250 $\mu 1$ chloroform and $100 \mathrm{ml}$ of $0.1 \%$ SDS) treatment. Out of 4 different treatments [sonication, lysozyme-EDTA, toluene-acetone and sodium dodecyl sulphate (SDS)-chloroform treatment] for $\beta$-galactosidase production, sonication treatment [V3 (1.093), NK2 (1.084) and NK9 (1.091)] was found to be best for production of $\beta$-galactosidase with optimized sonication period [5 min (pulse $15 \mathrm{sec}$ off / $30 \mathrm{sec}$ on at 55\% amplitudes)]. Purification of $\beta$-galactosidase enzyme was carried out employing various t-butanol ratios (crude extract : t-butanol $=1: 0.25,1.0: 0.5,1.0: 1.0,1.0: 1.5,1.0: 2.0)$ with a different ammonium sulfate saturation i.e. 30,60 and $90 \%$.After purification by treating with ratio of crude enzyme: $t$ butanol (R) and ammonium sulphate saturation (AS), $2 \%$ of R (0.396 O.D) and $60 \%$ of AS (0.292 O.D) showed maximum $\beta$-galactosidase activity for three selected Lactobacillus cultures i.e. V3, NK2 and NK9. The molecular mass of partially purified $\beta$ galactosidase (60\% Ammonium sulphate saturation) from selected Lactobacillus cultures i.e. V3, NK2 and NK9 as determined by SDS-PAGE was approx. $69 \mathrm{kDa}$. Therefore, the study entailed to conclude that production and purification of $\beta$-galactosidase enzyme from safe Lactobacillus cultures is an alternative source of biological enzyme for the preparation of lactose hydrolysed milk for lactose intolerant population.

\section{Introduction}

Lactose intolerance is due to lack of the enzyme lactase in the small intestines to break down the lactose into glucose and galactose (Deng et al., 2015). There are four types: primary, secondary, developmental and congenital. Primary lactose intolerance is when the amount of lactase declines as people age.
Secondary lactose intolerance is due to injury to the small intestine such as from infection, inflammatory bowel disease, celiac disease, or other diseases (Berni et al., 2016). Developmental lactose intolerance may occur in the premature babies and usually improves over a short period of time. Congenital lactose intolerance is an extremely 
rare genetic disorder in which no lactase is made from birth (NIDDK, 2016). In the family of $\beta$-galactosidase, lactase is one part of them which is a glycoside hydrolase. It is involved in the hydrolysis process of the disaccharide lactose into galactose and glucose monomers. Lactase is present in predominantly along with the brush border membrane of the differentiated enterocytes lining the villi of the small intestine (Skovbjerg et al., 1981).

Jelen et al., (1993) suggested that specific microbial strains that are high $\beta$-galactosidase producers could be used for lactose hydrolysis after cell disruption but with minimum additional purification. More recently, proposed a process for lactose hydrolysis in dairy systems using a crude enzymatic extract (CEE) from the Lactobacilli culture, with subsequent utilization of the fermentation medium used for the culture propagation (Vasiljevic and Jelen, 2001). Amongst lactic acid bacteria, yogurt bacteria (Lactobacillus bulgaricus and Streptococcus thermophilus) are the highest $\beta$ - galactosidase producers. The $\beta$-galactosidase of these cultures has been characterized, showing high stability and activity at high temperatures. However, the $\beta$ galactosidase from thermophilic LAB is an intracellular enzyme. It is release from microorganisms, which is obtained either by mechanical disruption or by the chemical permeabilization of the cell membrane. The effectiveness of the various disruption methods differs for different microbial genera and strains. Generally, $\beta$-galactosidase activity in the medium can be greatly increased by rupturing cells using different cell disruption methods. The literature tends to focus on the disruption of yeasts with much less information being available on the disruption of lactobacilli. (Bury et al., 2001). With this perspective, traditional yogurt samples obtained from Toros mountain region of Turkey with highly bio-diverse environment were used as the source for the isolation of LAB cultures. Almost 136 isolated strains were screened for $\beta$ galactosidase activity based on their lactose consumption and lactic acid producing characteristics according to the method described by Bury et al., (2001). Among these isolates only three Lactobacillus delbrueckii subsp. bulgaricus strains and three Streptococcus thermophilus strains showed a high potential. The activity and stability of $\beta$ galactosidase is strongly influenced by the enzyme origin and environmental conditions of the enzyme production and the hydrolysis process, such as temperature and $\mathrm{pH}$ optima, as well as the presence of activators or inhibitors. The use of CEEs instead of purified $\beta$-galactosidase preparation may complicate the final outcome of the hydrolysis due to the presence of other microbial enzymes, which may interfere with the lactose hydrolysis.

Prasad et al., (2013) evaluated that the production of $\beta$-galactosidase by Bifidobacterium animalis ssp. lactis $\mathrm{Bb} 12$ and Lactobacillus delbrueckii ssp. bulgaricus ATCC 11842 in whey and the effect of 4 different extraction methods i.e. sonication, acetone-toluene, SDS-chloroform and lysozyme-EDTA treatment on enzyme activity from these organisms. Among the four methods used for $\beta$-galactosidase extraction, sonication exhibited the best result (6.80 Unit $/ \mathrm{mL}$ ) for $B$. animalis ssp. lactis Bb12 while lysozyme-EDTA treatment was also found to be the best (7.77 Unit/ $\mathrm{mL}$ ) for L. delbrueckii ssp. bulgaricus ATCC 11842. Duman and Kaya, (2013) evaluated the activity of $\beta$-galactosidase was completely decreased at $60 \%$ ammonium sulfate saturation in aqueous phase, the best results of recovery and the purification fold of $\beta$ galactosidase (133\% and 10.1, respectively) was obtained in the interfacial phase. Higher salt concentrations from this point were 
resulted with reducing of recovery and purification fold, which may be due to irreversible denaturation of protein (Narayan et al., 2008).

Approximately $75 \%$ of Earth's population is lactose intolerant and in India (particularly southern India) $70 \%$ of the population are lactose intolerance and they feel uncomfortable whenever they consume milk and milk products. To meet this challenge, lactose hydrolysed milk is an alternative solution for proposed study. However the source of enzyme ( $\beta$-galactosidase) from biological material like LAB is an added advantage from safety point of view as LAB are having GRAS status.

\section{Materials and Methods}

Ten LAB cultures used in the present study i.e. L. helveticus MTCC 5463 (V3), L. rhamnosus (NK2), L. casei (NK9), L. rhamnosus MTCC 25062 (NK10), L. fermentum (M5), L. paracasei (M16), L. rhamnosus (M31), L. plantarum (M38), L. plantarum (M10), L. fermentum TDS030603 (LBF) were obtained from the Culture Collection of Dairy Microbiology Department, SMC College of Dairy Science, Anand Agricultural University, Anand. The LAB cultures were propagated in sterilized reconstituted skim milk (10\% TS) and stored at $5 \pm 2{ }^{\circ} \mathrm{C}$.

The transfer was given every week during the course of the study. Most the bacteriological media, molecular biology grade chemicals and reagents were purchased either from $\mathrm{Hi}^{-}$ Media (India), Sigma (USA), SDFCL (India), Chr. Hansen (Denmark) etc. During the entire study, glass wares of Borosil brand (Borosil Glass Works Ltd., Mumbai, India) and analytical grade and molecular biology grade chemicals were used. Glassware and other materials were sterilized by usual procedures viz. $160-180^{\circ} \mathrm{C}$ for $2 \mathrm{~h}$ in hot air oven, whenever required.

\section{Evaluation of $\mathrm{pH}$, acidity and Lactobacillus} counts of fermented skim milk

All the cultures were activated by growing in sterilized skim milk. The activated cultures were added to $100 \mathrm{ml}$ of skim milk flasks at the rate of $2 \%$. After mixing them thoroughly, the cultures were incubated at $37^{\circ} \mathrm{C}$ for different intervals of $0,6,12,18$ and $24 \mathrm{~h}$. Samples were taken out for determination of $\mathrm{pH}$, titratable acidity and viable counts after each interval. $\mathrm{pH}$ of fermented skim milk samples was measured using digital $\mathrm{pH}$ meter (OAKTON pH700, India).

The titratable acidity was estimated by the procedure described by (IS, 1960). Lactobacilli counts of fermented skim milk samples were determined as per the method described by IDF standards (146: 2003).Typical colonies were calculated and the counts were expressed as log cfu/ml.

\section{Determination of $\beta$-galactosidase activity}

All the cultures were activated by growing in MRS broth. The activated cultures were added to $100 \mathrm{ml}$ of MRS broth at the rate of $2 \%$. After mixing them thoroughly, the culture flasks were incubated at $37^{\circ} \mathrm{C}$ for different intervals of $0,24,48$ and $72 \mathrm{~h}$. Samples were taken out for $\beta$-galactosidase activity at each interval.

\section{Enzyme extraction}

After $0,24,48$ and $72 \mathrm{~h}$ of incubation, the cells were harvested by centrifuging at 5000 rpm for $15 \mathrm{~min}$ at $4{ }^{\circ} \mathrm{C}$. The supernatant was considered to be containing extracellular enzymes. The cell pellet was crushed and washed twice with a $0.05 \mathrm{M}$ sodium phosphate buffer ( $\mathrm{pH}$ 6.8) and centrifuged at 
$5000 \mathrm{rpm}$ for $15 \mathrm{~min}$ at $4^{\circ} \mathrm{C}$. The washed pellets were resuspended in $10 \mathrm{~mL}$ of $0.05 \mathrm{M}$ phosphate buffer $(\mathrm{pH}$ 6.8) for intracellular enzyme extraction using cell disintegration methods listed below (Prasad et al., 2013):

\section{Sonication treatment}

The cell suspensions were sonicated for 30 min (pulse 30 seconds off / 30 seconds on and $61 \%$ amplitudes) in ice bath using sonicator (LABMAN, India), according to the method described by Prasad et al., (2013).

The extract was then centrifuged at $5000 \mathrm{rpm}$ at $4{ }^{\circ} \mathrm{C}$ for $15 \mathrm{~min}$ and the supernatant containing the crude enzyme extract was stored at $-20^{\circ} \mathrm{C}$ until used for enzyme assays.

\section{Enzyme assay}

The $\beta$-galactosidase was determined by the reaction mixture was composed of $0.5 \mathrm{~mL}$ of supernatant containing extracted enzyme and $2.0 \mathrm{~mL}$ of $15 \mathrm{mM}$ O-nitrophenyl $\beta$-Dgalactopyranoside (ONPG) in $0.05 \mathrm{M}$ sodium phosphate buffer ( $\mathrm{pH}$ 6.8). After incubation for $20 \mathrm{~min}$ at $37^{\circ} \mathrm{C}, 0.5 \mathrm{~mL}$ of $0.1 \mathrm{M}$ sodium carbonate was added to the mixture to stop the reaction.

Absorbance was measured at $420 \mathrm{~nm}$ with a spectrophotometer (Systronics PC based double beam spectrophotometer 2202, India).

\section{Production, extraction and purification of $\beta$-galactosidase from selected LAB}

All the cultures were activated by growing in MRS broth. The activated cultures were added to $100 \mathrm{ml}$ of MRS broth flasks at the rate of $2 \%$. After mixing them thoroughly, the culture flasks were incubated at $37^{\circ} \mathrm{C}$ for $24 \mathrm{~h}$. Samples were taken out for $\beta$-galactosidase activity.

\section{Enzyme extraction}

After $24 \mathrm{~h}$ of incubation, the cells were harvested by centrifuging at $5000 \mathrm{rpm}$ for 15 $\min$ at $4{ }^{\circ} \mathrm{C}$. The supernatant was considered to be containing extracellular enzymes. The cell pellet was crushed and washed twice with a $0.05 \mathrm{M}$ sodium phosphate buffer $(\mathrm{pH}$ 6.8) and centrifuged at $5000 \mathrm{rpm}$ for $15 \mathrm{~min}$ at $4^{\circ} \mathrm{C}$. The washed pellets were resuspended in $10 \mathrm{~mL}$ of $0.05 \mathrm{M}$ phosphate buffer ( $\mathrm{pH}$ 6.8) for intracellular enzyme extraction using four different cell disintegration methods listed below (Prasad et al., 2013):

\section{Sonication treatment}

The cell suspensions were sonicated for 3,4 and 5 minute intervals (pulse 15 seconds off / 30 seconds on as well as 35 and $55 \%$ amplitudes) in ice bath using sonicator (LABMAN, India), according to the method mentioned by Prasad et al., (2013). The extract was then centrifuged at $5000 \mathrm{rpm}$ and $4^{\circ} \mathrm{C}$ for $15 \mathrm{~min}$ and the supernatant containing the crude enzyme was stored at $-20^{\circ} \mathrm{C}$ until used for enzyme assays.

\section{Lysozyme EDTA treatment}

Lysozyme solution was prepared by dissolving $49 \mathrm{mg}$ of lysozyme (Hi-Media, India) in $1.5 \mathrm{~mL}$ of TE (Tris-EDTA; Ethylenediamine Tetraacetic Acid) buffer containing $1 \mathrm{mM}$ EDTA and $10 \mathrm{mM}$ Tris$\mathrm{HCl}$, adjusted to $\mathrm{pH}$ 8.0. The lysozyme preparation was added to the cell suspension at the rate of $150 \mu \mathrm{L}$ per $\mathrm{mL}$, incubated for 45 min at room temperature. Then supernatant obtained was kept at $-20^{\circ} \mathrm{C}$ until enzyme activity measurement (Prasad et al., 2013).

\section{Toluene acetone treatment}

$10 \mathrm{ml}$ cell suspension was ground for $10 \mathrm{~min}$ in a pestle and mortar with $2.0 \mathrm{~g}$ alumina 
(SDFCL, India) and 0.2 mL of 9:1 mixture of toluene (LOBA Chemie, India with $99.5 \%$ purity) and acetone (LOBA Chemie, India with $99.8 \%$ purity) solvents. The suspension was extended in $8 \mathrm{~mL}$ phosphate buffer and centrifuged at $5000 \mathrm{rpm}$ for $15 \mathrm{~min}$ at $4^{\circ} \mathrm{C}$. The supernatant obtained was kept at $-20^{\circ} \mathrm{C}$ until used for enzyme assay (Prasad et al., 2013).

\section{Sodium dodecyl sulphate (SDS) - Chloroform treatment}

Permeabilization of cell membrane was carried out by vortexing $10 \mathrm{~mL}$ of the cell suspension in the presence of $250 \mu \mathrm{L}$ chloroform and $100 \mu \mathrm{L} 0.1 \%$ SDS solution for $30 \mathrm{~min}$ at room temperature. The suspension was centrifuged at $5000 \mathrm{rpm}$ for $15 \mathrm{~min}$ at $4^{\circ} \mathrm{C}$ and the supernatant was kept at $-20^{\circ} \mathrm{C}$ until needed for the enzyme assay (Prasad et al., 2013).

Quantitative analysis of $\boldsymbol{\beta}$-galactosidase activity produced by selected Lactobacillus cultures through $\mathrm{X}$-Gal assay

\section{Sonication treatment}

The cell suspensions were sonicated for $5 \mathrm{~min}$ (pulse 15 seconds off / 30 seconds on and $55 \%$ amplitudes) in ice bath using sonicator (LABMAN, India), according to the method described by Prasad et al., (2013).

The extract was then centrifuged at $5000 \mathrm{rpm}$ at $4^{\circ} \mathrm{C}$ for $15 \mathrm{~min}$ and the supernatant containing the crude enzyme extract was stored at $-20^{\circ} \mathrm{C}$ until used for further study.

\section{X-gal-IPTG treatment}

$2 \mathrm{ml}$ of crude $\beta$-galactosidase enzyme was added in the mixture of $0.5 \mathrm{ml}$ of $\mathrm{X}$-gal (chromogenic substrate) and $0.5 \mathrm{ml}$ of 0.1 [M] isopropyl $\beta$-D-1-thiogalactopyrinoside (IPTG) and incubated for $3 \mathrm{~h}$ at $37^{\circ} \mathrm{C}$ in water bath. After incubation, the $\beta$-galactosidase activity was measured using absorbance at $550 \mathrm{~nm}$ with a spectrophotometer (Systronics PC based double beam spectrophotometer 2202, India) depending on the intensity of the developed blue colour.

\section{Purification of $\beta$-galactosidase enzyme}

Purification of $\beta$-galactosidase enzyme was carried out employing various t-butanol ratios (crude extract: t-butanol $=1: 0.25,1.0: 0.5$, $1.0: 1.0,1.0: 1.5,1.0: 2.0)$ with a different ammonium sulfate saturation at 30,60 and $90 \%$. The mixture was mixed gently and then allowed to stand for $30 \mathrm{~min}$ at $37^{\circ} \mathrm{C}$. afterward, the mixture was centrifuged at $5000 \mathrm{rpm}$ for $15 \mathrm{~min}$ at $4^{\circ} \mathrm{C}$ to facilitate the separation of phases. The upper t-butanol phase was removed by the Pasteur pipette. The lower aqueous phase and the interfacial phase were separated carefully and each of phases were analyzed for enzyme activity. Different ammonium sulfate saturation effects $(30,60$ and 90\%) (w/v) were investigated at the best recovery activity of crude enzyme:tbutanol ratio that is 1.0:1.0. The bottom phase and interfacial phase were analyzed for enzyme activity (Duman and Kaya, 2013).

\section{Purification of $\beta$-galactosidase enzyme through SDS-PAGE}

The SDS-PAGE was performed following method of Laemmli (1970); Carrasco-Castilla et al., (2012) with some modifications to identify the molecular weight of partially purified $\beta$-galactosidase enzyme.

\section{Results and Discussion}

\section{Growth behavior of Lactobacillus cultures}

During the evaluation of $\beta$-galactosidase activity, the Lactobacillus cultures were 
inoculated at the rate of $2 \%$ in sterilized reconstituted skim milk. Then $\mathrm{pH}$, titratable acidity (\% Lactic acid) and Lactobacillus counts were estimated at different time intervals $(0,6,12,18$ and $24 \mathrm{~h})$ at $37^{\circ} \mathrm{C}$. The titratable acidity (\% Lactic acid), $\mathrm{pH}$ and Lactobacillus counts of individual Lactobacillus culture were evaluated and depicted in figures 1,2 and 3 respectively. Titratable acidity was determined by calculating the amount of titratable acidity developed up to $24 \mathrm{~h}$ of incubation. From the figure 1, it was observed that the titratable acidity of $\mathrm{V} 3$ was significantly $(\mathrm{P}<0.05)$ increased up to $24 \mathrm{~h}$. The titratable acidity was significantly higher at $24 \mathrm{~h}$ (1.109). Overall titratable acidity was ranged from $0.141 \%$ LA (0h) to $1.109 \%$ LA after $24 \mathrm{~h}$ incubation at $37^{\circ} \mathrm{C}$. During the growth in sterilized reconstituted skim milk, V3 produced highest titratable acidity ( $0.704 \%$ LA), followed by M5 $(0.691 \%)$ and NK9 $(0.630 \%)$ after $24 \mathrm{~h}$ at $37^{\circ} \mathrm{C}$. From figure 2 , it was also observed that the $\mathrm{pH}$ of $\mathrm{V} 3$ was significantly $(\mathrm{P}<0.05)$ decreased up to $24 \mathrm{~h}$ of incubation period. The $\mathrm{pH}$ was significantly lowered at 24h (4.04). Overall $\mathrm{pH}$ was ranged from $6.56(0 \mathrm{~h})$ to 4.04 after $24 \mathrm{~h}$ at $37^{\circ} \mathrm{C}$. During the growth in sterilized reconstituted skim milk, V3 produced highest reduction in $\mathrm{pH}$ (4.89), followed by M5 (4.97) and NK9 (5.00) after $24 \mathrm{~h}$ at $37^{\circ} \mathrm{C}$. From figure 3, it was observed that the Lactobacillus counts $(\log \mathrm{cfu} / \mathrm{ml})$ of V3 was significantly $(\mathrm{P}<0.05)$ increased up to $24 \mathrm{~h}$ of incubation period. Lactobacillus counts $(\log \mathrm{cfu} / \mathrm{ml})$ were significantly maximum at $24 \mathrm{~h}$ (9.701). Overall Lactobacillus counts $(\log \mathrm{cfu} / \mathrm{ml})$ were ranged from $6.486 \log \mathrm{cfu} / \mathrm{ml}(0 \mathrm{~h})$ to $9.701 \mathrm{log}$ $\mathrm{cfu} / \mathrm{ml}$ after $24 \mathrm{~h}$ incubation at $37^{\circ} \mathrm{C}$. During the growth in sterilized reconstituted skim milk, V3 showed maximum Lactobacillus counts $(8.892 \log \mathrm{cfu} / \mathrm{ml})$, followed by NK10 (8.481 log $\mathrm{cfu} / \mathrm{ml})$ and LBF (8.425 log $\mathrm{cfu} / \mathrm{ml})$ after $24 \mathrm{~h}$ at $37{ }^{\circ} \mathrm{C}$.
Hati et al., (2015) studied the growth performance of Lctobcillus rhamnosus (NS4 and NS6), Lactobacillus helveticus MTCC 5463 (V3), Lactobacillus delbruckii (09), Enterococcus feacalis (ND3), Enterococcus feacalis (ND11) and Lactobacillus rhamnosus (SH8) by determining viable counts (log $\mathrm{cfu} / \mathrm{ml}$ ) and production of Lactobacillus acid measured by decline in $\mathrm{pH}$ in skim milk inoculated at the rate of $1 \%$ and incubated at $37{ }^{\circ} \mathrm{C}$ for $12 \mathrm{~h}$. It was observed that NS4 lowered down the $\mathrm{pH}$ at a maximum level compared to V3, ND3 and SH8. However, it was also observed that NS4 produced maximum acidity compared to V3, ND3, SH8 and $\mathrm{I} 4$.

Viable counts of all the cultures were measured after $12 \mathrm{~h}$ of incubation at $37{ }^{\circ} \mathrm{C}$. From the study; it was found that NS4 gives highest viable cell counts $10.68 \mathrm{log} \mathrm{cfu} / \mathrm{ml}$ than other bacterial isolates at this qrelatively exhibited lesser bacterial counts compared to other isolates in MRS agar medium. It was also concluded that, viable cell counts, $\mathrm{pH}$ and acidity varies due to the use of different strains (Hati et al., 2015) as similar to our study. In another study, Hati et al., (2017) evaluated the influence of whey protein concentrate on the production of antibacterial peptides derived from fermented milk by Lactic Acid Bacteria. They evaluated skim milk supplemented with WPC 70 (@ 1.0, 1.5, $2 \%$ ) was inoculated with $2 \%$ lactic cultures i.e., S. thermophilus (MD2), L. helveticus (V3), L. rhamnosus (NS4) and L. bulgaricus (09). $\mathrm{pH}$, titratable acidity, viable cell counts and proteolytic activity were evaluated after $3,6,9,12$ and $24 \mathrm{~h}$ of fermentation at $37^{\circ} \mathrm{C}$. It has been previously reported that addition of WPC 70 to milk followed by heat treatment induced a decrease of fermentation time (Antunes et al., 2005; Milanovic et al., 2009). It has been also reported that addition of 1 or $2 \%$ WPC to a medium used for fermentation with L. delbrueckii ssp. bulgaricus or $S$. 
thermophilus has produced significantly higher bacterial counts and much faster acidity (Burya et al., 1998).

\section{Determination of $\beta$-galactosidase activity}

Out of ten Lactobacillus cultures three cultures were selected on the basis of $\beta$ galactosidase activity. $\beta$-galactosidase activity of Lactobacillus cultures were carried out in MRS medium using sonicator (LABMAN, India) for $30 \mathrm{~min}$ (30 seconds off / 30 seconds on and $61 \%$ amplitudes) in ice bath, according to the method of Prasad et al., (2013). Individually each Lactobacillus culture was statistically analyzed for the production of $\beta$-galactosidase enzyme at optimum incubation period. $\beta$-galactosidase enzyme production of ten Lactobacillus cultures in MRS medium was depicted in the figure 4 .

From the figure 4 , it was observed that the $\beta$ galactosidase activity of V3 was significantly $(\mathrm{P}<0.05)$ increased up to $24 \mathrm{~h}$ of incubation. The $\beta$-galactosidase activity was significantly higher at $24 \mathrm{~h}$ (1.444 O.D.) for all the Lactobacillus cultures compared to $48 \mathrm{~h}$ (0.467 O.D.) and $72 \mathrm{~h}$ (0.193 O.D.). V3 showed highest (1.023 O.D.) $\beta$-galactosidase activity at $24 \mathrm{~h}$. Overall $\beta$-galactosidase activity was ranged from 0.113 O.D. (LBF at Oh) to 3.381 O.D. (V3 up to 24h). V3 produced the maximum $\beta$-galactosidase activity at $24 \mathrm{~h}$ (3.381 O.D.), followed by NK2 (2.502 O.D) and NK9 (2.417 O.D). Overall $\beta$ galactosidase activity was ranged from M16 (0.149 O.D) to V3 (1.023 O.D).

Vikas et al., (2015) studied the efficiency of different methods for disruption of Streptococcus thermophilus cells, isolated from different dairy products, to release $\beta$ galactosidase and synthesis of Galacto oligosaccharides (GOS) by extracted enzyme using whey supplemented with different concentrations of lactose as a substrate was studied. Unlike most other studies on GOS synthesis which used only one method of cell disruption sonication (ultrasonics) and only few microbial strains, they compared five different cell disruption methods and used 30 strains of $S$. thermophilus in order to find out the most effective method is sonication (ultrasonics) and efficient strain for production of $\beta$-galactosidase. This report had a similar method from our study. In another study, Prasad et al., (2013) studied the activity of $\beta$-galactosidase from $B$. animalis Bb12 and L. delbrueckii ssp. bulgaricus ATCC 11842 in whey and its extraction using various methods. L. delbrueckii ssp. bulgaricus ATCC 11842 produced more $(\mathrm{p}<0.05)$ intracellular $\beta$-galactosidase than $B$. animalis ssp. lactis $\mathrm{Bb} 12$ with all extraction methods, except sonication. There were significant $(\mathrm{p}<0.05)$ differences in $\beta$ galactosidase levels extracted from each organism by the four extraction methods. Sonication method was found to be more effective for $B$. animalis Bb12 than the others methods. This report had a similar observation from our study. In another study, Kara (2004) evaluated the release and characterization of $\beta$-galactosidase from Lactobacillus plantarum. She optimized the lysozyme method, sonication method, and liquid nitrogen method for protein release from the cells of Lactobacillus plantarum. Sonication was found to be the most effective method. This report had a similar method from our study.

The aim of this study was to screen different Lactobacillus cultures on the basis of $\beta$ galactosidase activity and to optimize the growth conditions for the production of $\beta$ galactosidase enzyme of Lactobacillus cultures. Two important fermentation variables i.e., ten Lactobacillus cultures ( $L$. helveticus MTCC 5463 (V3), L. rhamnosus (NK2), L. casei (NK9), L. rhamnosus MTCC 
25062 (NK10), L. fermentum (M5), $L$. paracasei (M16), L. rhamnosus (M31), L. plantarum (M38), L. plantarum (M10), L. fermentum TDS030603 (LBF)) and incubation periods $(0,24,48$ and $72 \mathrm{~h})$ were studied. As per statistical analysis, V3, NK2 and NK9 were found to be strong $\beta$ galactosidase producer at $24 \mathrm{~h}$ of incubation. As, the degree of $\beta$-galactosidase activity was found to depend on different strains of Lactobacillus cultures and incubation period i.e. 24 hours, V3, NK2 and NK9 Lactobacillus cultures were selected for the production of $\beta$-galactosidase enzyme. $\beta$ galactosidase activity being important factor for the $\beta$-galactosidase production, the variables studied were very relevant due to their significance in improving the $\beta$ galactosidase enzyme production from both the microorganisms and optimum growth temperature (24h).

Production, extraction and purification of $\beta$-galactosidase from selected LAB

Selected Lactobacillus cultures i.e. L.helveticus MTCC 5463 (V3), L.rhamnosus (NK2), L.casei (NK9) were considered to production, extraction and purification of $\beta$ galactosidase enzyme. This Lactobacillus cultures were activated by growing in $100 \mathrm{ml}$ of MRS broth flasks at the rate of $2 \%$ at $37^{\circ} \mathrm{C}$ for $24 \mathrm{~h}$. After $24 \mathrm{~h}$ of incubation, the cells were harvested by centrifuging at 5000rpm for $15 \min$ at $4^{\circ} \mathrm{C}$.

The supernatant was considered to be containing extracellular enzymes. The cell pellet was crushed and washed twice with a $0.05 \mathrm{M}$ sodium phosphate buffer ( $\mathrm{pH}$ 6.8) and centrifuged at $5000 \mathrm{rpm}$ for $15 \mathrm{~min}$ at $4^{\circ} \mathrm{C}$. The washed pellets were resuspended in 10 $\mathrm{mL}$ of $0.05 \mathrm{M}$ phosphate buffer ( $\mathrm{pH}$ 6.8) for intracellular enzyme extraction using four different cell disintegration methods listed below:

\section{Sonication treatment}

The cell suspensions were sonicated for 3,4 and 5 minutes intervals (pulse 15 seconds off $/ 30$ seconds on as well as 35 and 55\% amplitudes) in ice bath using probe sonicator (LABMAN, India), according to the modified method of Prasad et al., (2013). The extract was then centrifuged at $5000 \mathrm{rpm}$ at $4^{\circ} \mathrm{C}$ for $15 \mathrm{~min}$ and the supernatant containing the crude enzyme was stored at $-20^{\circ} \mathrm{C}$ for further used. Lactobacillus cultures i.e. V3, NK2 and NK9 were statistically analysed for the different time intervals of sonication along with different $\%$ of amplitudes of sonication for highest production of $\beta$-galactosidase enzyme. $\beta$-galactosidase production of Lactobacillus cultures i.e. V3, NK2 and NK9 were represented in figure 5 .

It is evident from the figure 5 that the $\beta$ galactosidase production of V3 was significantly $(\mathrm{P}<0.05)$ increased with the \% amplitude (from 35 to $55 \%$ ) and residence time interval (from 3 to $5 \mathrm{~min}$ ) during the sonication. $\beta$-galactosidase activity was significantly maximum at $55 \%$ amplitude for all the time intervals (3, 4 and $5 \mathrm{~min}$ ) than 35 $\%$ amplitude.

Significantly maximum $\beta$-galactosidase activity was observed at $55 \%$ amplitude and 5 min (1.442 O.D) followed by 4 min (1.076 O.D) and 3 min (0.943 O.D) compared to 35 $\%$ amplitude and $5 \mathrm{~min}$ (1.255 O.D) followed by $4 \mathrm{~min}$ (1.017 O.D) and $3 \mathrm{~min}$ (0.804 O.D). From figure 5, it was observed that the $\beta$ galactosidase activity of V3, NK2 and NK9 cultures were significantly $(\mathrm{P}<0.05)$ increased with the different amplitude (35 and $55 \%$ ) and time intervals (3,4 and $5 \mathrm{~min}$ ) between pulses in sonication treatment. Significantly maximum $\beta$-galactosidase activity was observed in V3 culture (1.093 O.D) followed by NK9 (1.091 O.D) and NK2 (1.084 O.D). 


\section{Lysozyme EDTA treatment}

Lysozyme solution was prepared by dissolving $49 \mathrm{mg}$ of lysozyme (Hi-Media, India) in $1.5 \mathrm{~mL}$ of TE (Tris-EDTA; Ethylenediamine Tetraacetic Acid) buffer containing $1.0 \mathrm{mM}$ EDTA and $10 \mathrm{mM}$ Tris$\mathrm{HCl}$, adjusted to $\mathrm{pH}$ 8.0. $150 \mu \mathrm{L}$ lysozyme preparation was added to the cell suspension and incubated for $45 \mathrm{~min}$ at room temperature. Then supernatant obtained was kept at $-20^{\circ} \mathrm{C}$ for further study (Prasad et al., 2013). From the figure 6 , it was observed that the $\beta$-galactosidase activity of $\mathrm{V} 3$, culture was significantly $(\mathrm{P}<0.05)$ higher than NK9 and NK2. V3 culture was also exhibited maximum $\beta$-galactosidase activity $(0.124$ O.D), followed by NK9 and NK2 (0.103 O.D).

Fig.1 Evaluation of lactic acid production by Lactobacillus cultures in Reconstituted Skim Milk

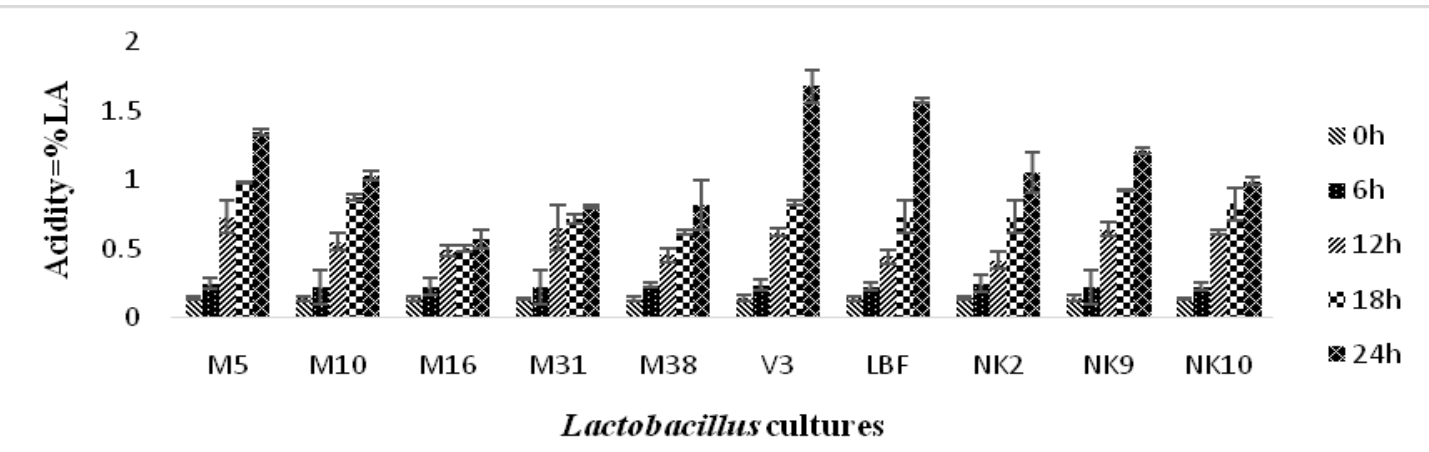

Fig.2 Changes in pH of Reconstituted Skim Milk produced by Lactobacillus cultures

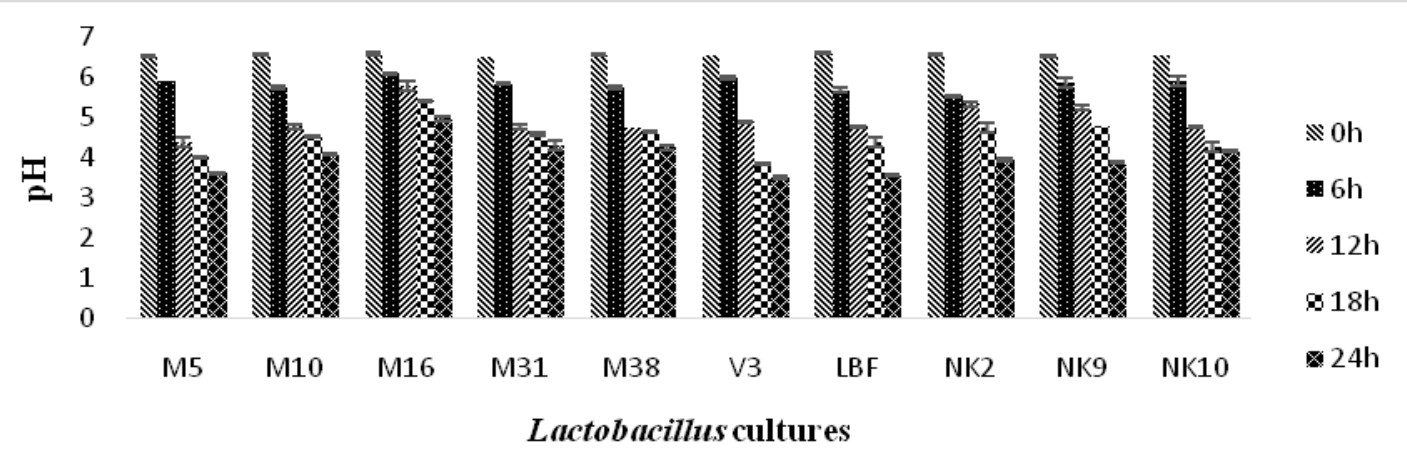

Fig.3 Evaluation of Lactic Counts of Lactobacillus cultures in Reconstituted Skim Milk

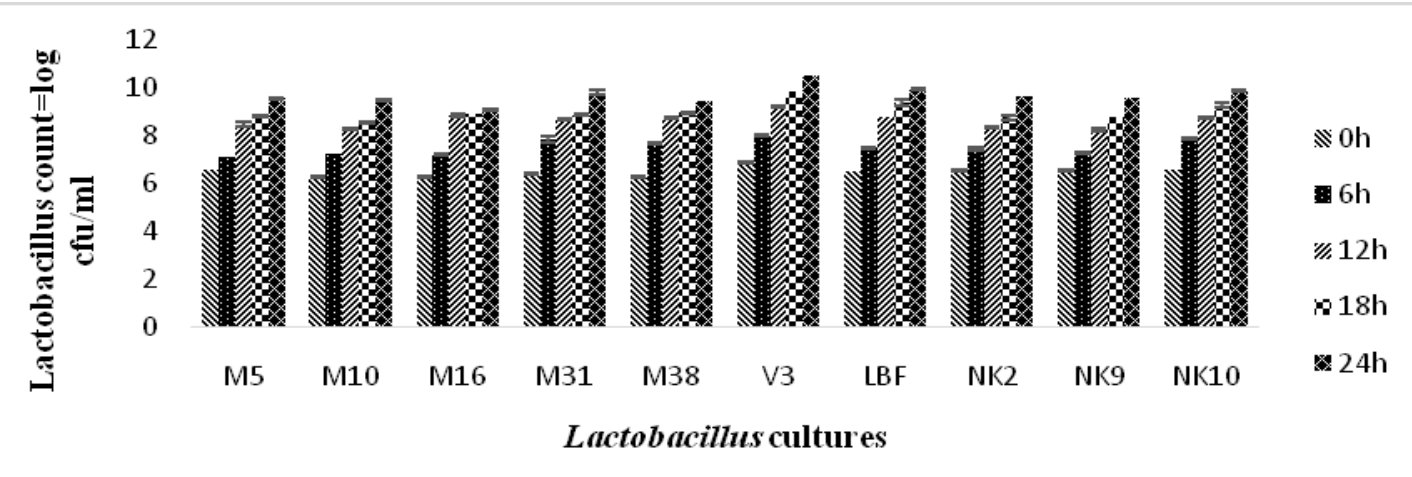


Fig.4 $\beta$-galactosidase activity of Lactobacillus cultures for different incubation periods

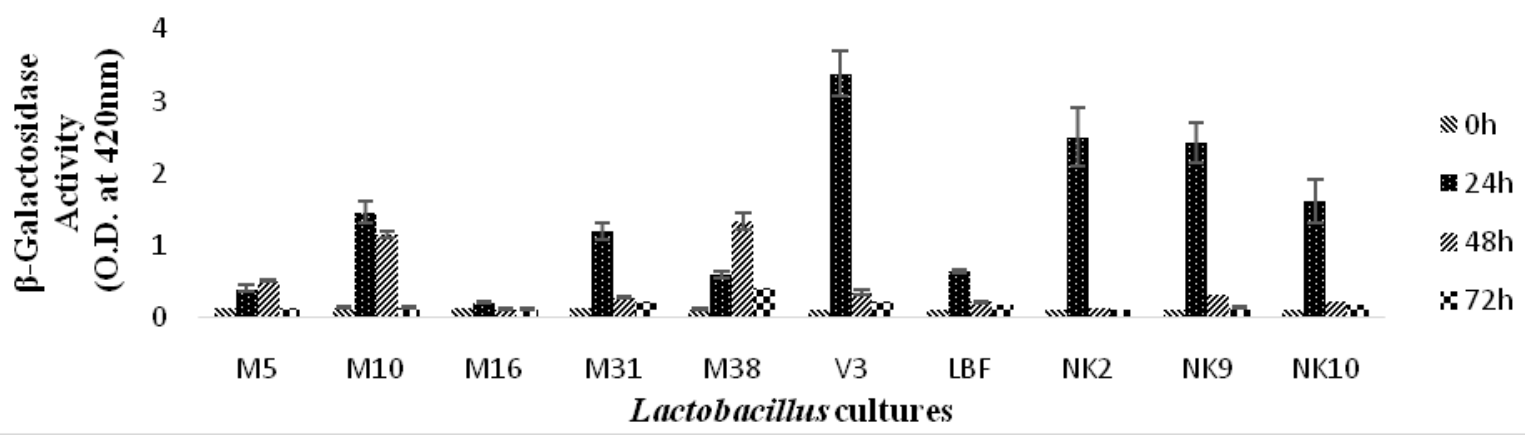

Fig.5 Effect of duration and amplitudes on $\beta$-galactosidase activity

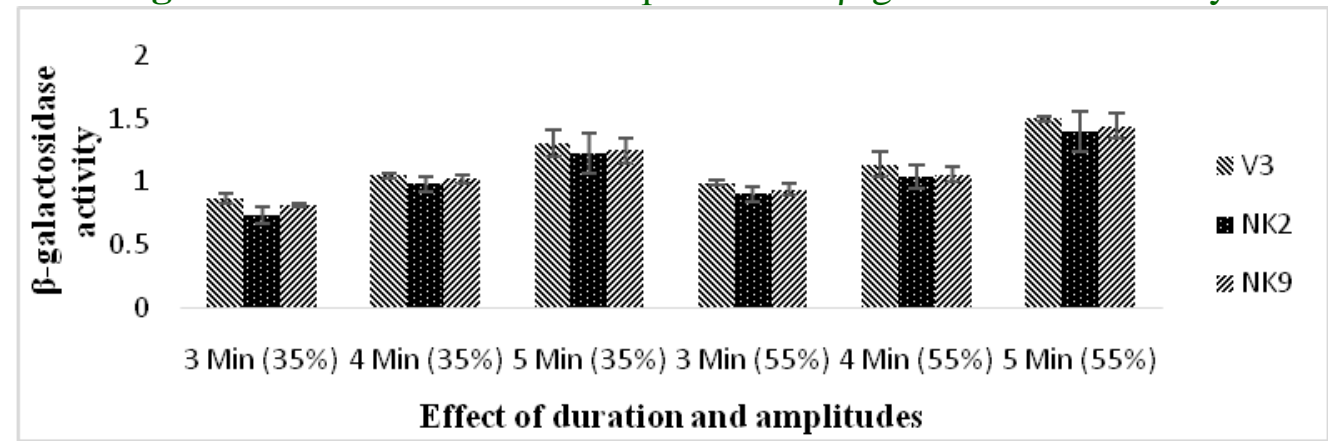

Fig.6 Effect of lysozyme EDTA treatment on $\beta$-galactosidase activity

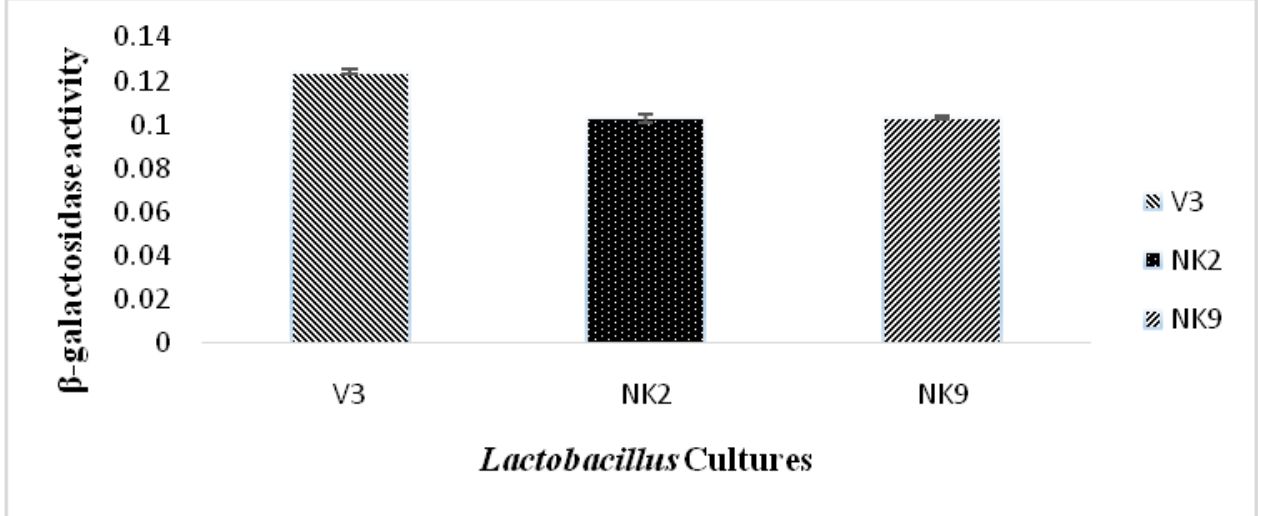

Fig.7 Effect of toluene acetone treatment on $\beta$-galactosidase activity

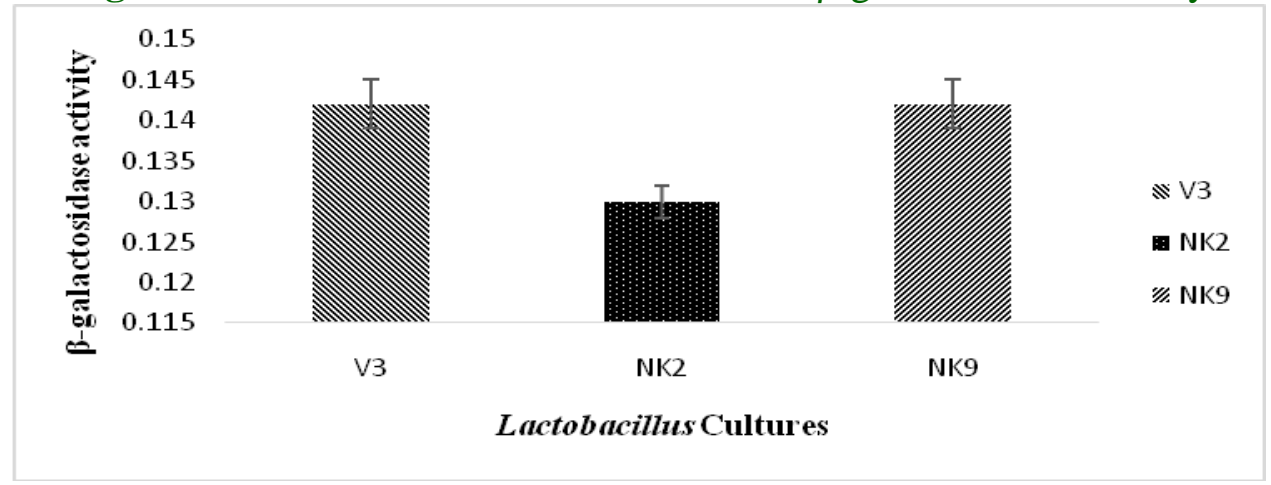


Fig.8 Effect of Sodium dodecyl sulphate (SDS) - chloroform treatment on $\beta$-galactosidase activity

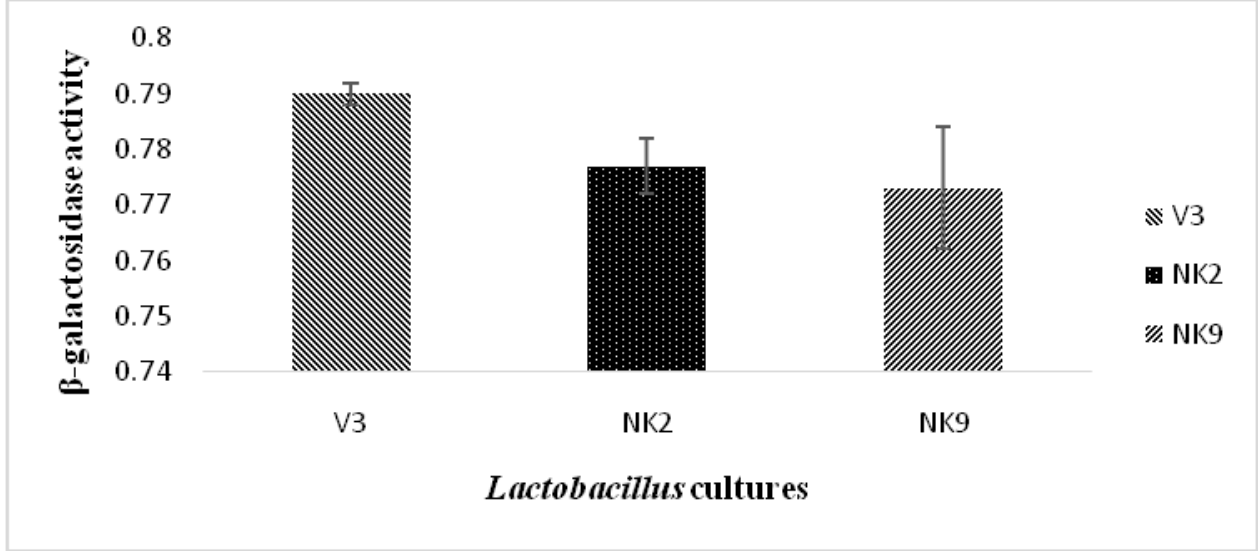

Fig.9 Evaluation of $\beta$-galactosidase activity of Lactobacillus cultures using X-gal

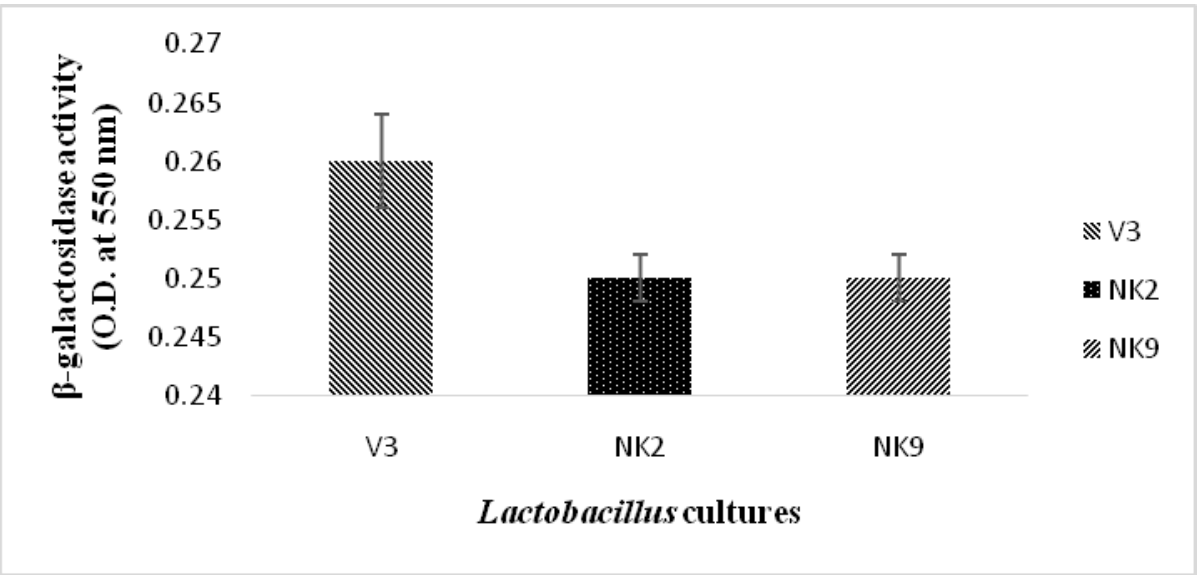

Fig.10 Effect of ammonium sulphate saturation (AS) and Ratio of crude enzyme: t-butanol (R) on $\beta$-galactosidase activity of selected Lactobacillus cultures

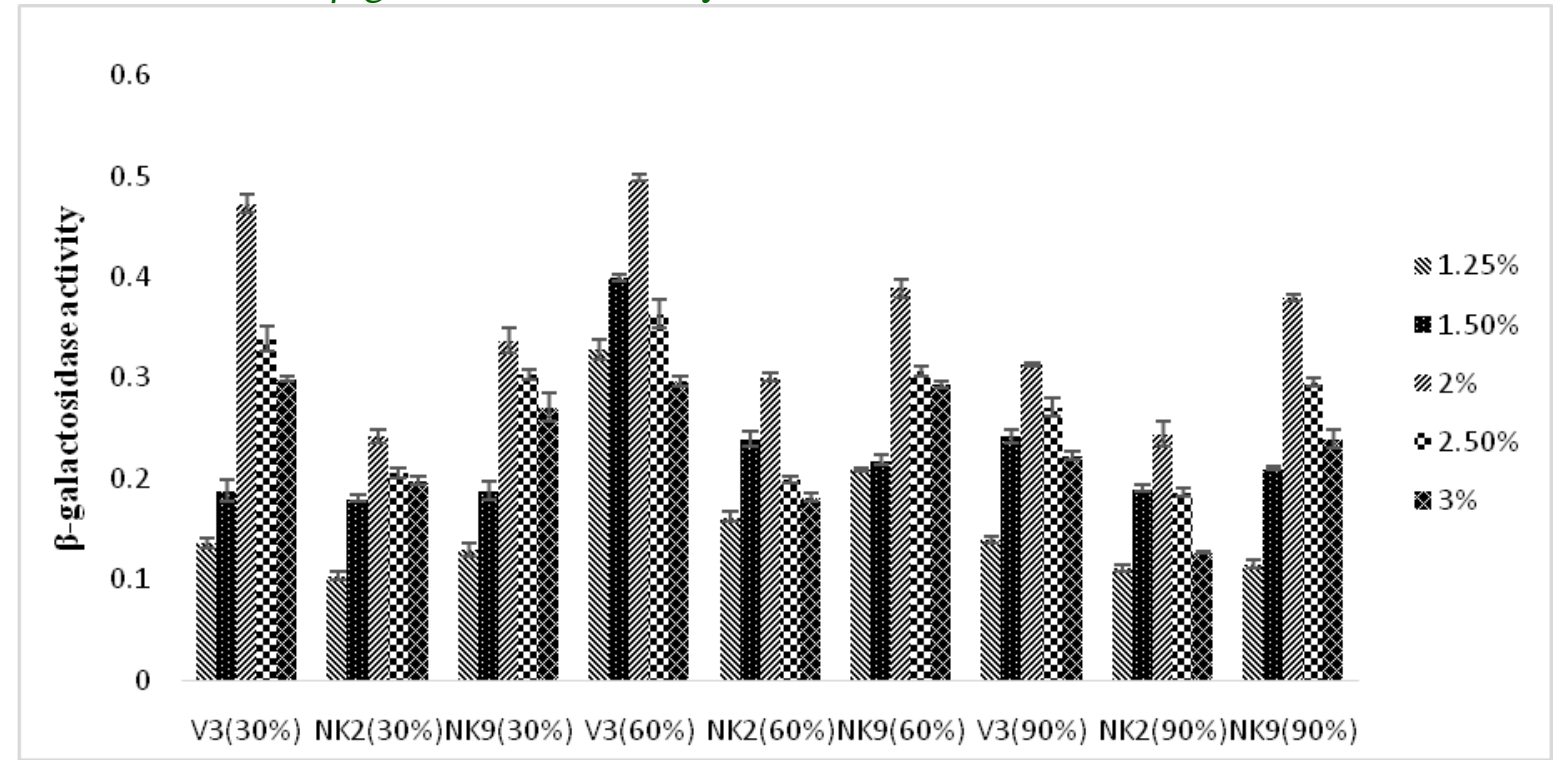


Fig.11 $\beta$-galactosidase profile of LAB revealed by SDS-PAGE 1234

Lane 1, Bovine serum albumin (BSA- 66.2 kDa); Lane 2, V3; Lane 3, NK2; Lane 4, NK9.

\section{Toluene acetone treatment}

In Toluene acetone treatment, $10 \mathrm{ml}$ cell suspension was ground for $10 \mathrm{~min}$ in a pestle and mortar with $2.0 \mathrm{~g}$ alumina (SDFCL, India) and $0.2 \mathrm{~mL}$ of $9: 1$ mixture of toluene (LOBA Chemie, India with $99.5 \%$ purity) and acetone (LOBA Chemie, India with $99.8 \%$ purity) solvents. The suspension was extended in $8 \mathrm{~mL}$ phosphate buffer and centrifuged at $5000 \mathrm{rpm}$ for $15 \mathrm{~min}$ at $4^{\circ} \mathrm{C}$. The supernatant obtained was kept at $-20^{\circ} \mathrm{C}$ for future enzyme assay (Prasad et al., 2013).

From figure 7 , it was observed that the $\beta$ galactosidase activity of V3 and NK9 cultures were significantly $(\mathrm{P}<0.05)$ higher than $\mathrm{NK} 2$. V3 and NK9 cultures were also exhibited maximum $\beta$-galactosidase activity (0.142 O.D) than NK2 (0.130 O.D).

\section{Sodium dodecyl sulphate (SDS) - Chloroform treatment}

In SDS-Choloroform treatment, permeabilization of cell membrane was carried out by vortexing $10 \mathrm{~mL}$ of the cell suspension in the presence of $250 \mu \mathrm{L}$ chloroform and 100 $\mu \mathrm{L} 0.1 \%$ SDS solution for $30 \mathrm{~min}$ at room temperature. The suspension was centrifuged at $5000 \mathrm{rpm}$ for $15 \mathrm{~min}$ at $4^{\circ} \mathrm{C}$ and the supernatant was kept at $-20^{\circ} \mathrm{C}$ for further enzyme assay.
From the figure 8 , it was observed that the $\beta$ galactosidase activity of $\mathrm{V} 3$ culture was significantly $(\mathrm{P}<0.05)$ higher than $\mathrm{NK} 2$ and NK9. V3 culture was also exhibited maximum $\beta$-galactosidase activity (0.790 O.D) followed by NK2 (0.777 O.D) and NK9 (0.773).

Out of 4 different treatments [Sonication, Lysozyme-EDTA, Toluene-Acetone and Sodium dodecyl sulphate (SDS) - Chloroform Treatment] for $\beta$-galactosidase production, sonication treatment \{V3(1.093), NK2(1.084) and NK9(1.091)\} was found to be best for production of $\beta$-galactosidase with optimized sonication period: $5 \mathrm{~min}$ (pulse $15 \mathrm{sec}$ off / 30 $\mathrm{sec}$ on at 55\% amplitudes) [Sonication treatment > Sodium dodecyl sulphate (SDS) Chloroform Treatment) > Toluene-Acetone treatment > Lysozyme EDTA treatment].

Quantitative analysis of $\beta$-galactosidase activity produced by selected Lactobacillus cultures through $\mathrm{X}$-Gal assay

$\beta$-galactosidase enzymes are lactose hydrolytic enzymes that are involved in catalytic process of lactose found in milk and make it as best industrial product for lactose intolerant population. The enzyme also regulates the transgalactosylation reactions in order to synthesize galactooligosaccharides. Considering their tremendous applications in different industries, various bacterial strains were 
isolated and screened for $\beta$-galactosidase production (Kamaran et al., 2016).

$2 \mathrm{ml}$ of crude $\beta$-galactosidase enzyme was added into the mixture of $0.5 \mathrm{ml}$ of $\mathrm{X}$-gal and $0.5 \mathrm{ml}$ of $0.1 \mathrm{M}$ IPTG and incubated for $3 \mathrm{~h}$ at $37^{\circ} \mathrm{C}$. After incubation it was measured at 550 $\mathrm{nm}$ with a spectrophotometer (Systronics PC based double beam spectrophotometer 2202, India) of $\beta$-galactosidase activity of V3, NK2 and NK9 and was represented in figure 9 using $X$-gal and IPTG. $\beta$-galactosidase activity produced by Lactobacillus cultures was determined in ranged from 0.25 O.D to 0.26 O.D. After $3 \mathrm{~h}$ of incubation at $37^{\circ} \mathrm{C}$. V3 showed maximum $\beta$-galactosidase activity (0.26 O.D) compared to NK2 and NK9 (0.25 O.D).

Kamran et al., (2016) evaluating the qualitative screening of bacterial isolates for $\beta$ galactosidase production. Pure bacterial cultures were grown at $37^{\circ} \mathrm{C}$ for $48 \mathrm{~h}$ onto the lactose agar medium, supplemented with $50 \mu \mathrm{g} \mathrm{ml}^{-1} \mathrm{X}$ gal (chromogenic substrate) and $1.0 \mathrm{mM}$ of isopropyl $\beta$-d-1-thiogalactopyrinoside (IPTG) to examine the capability of isolates for $\beta$ galactosidase production (Jaturapiree et al., 2012). Lactose agar medium contained $\left(\mathrm{g} \mathrm{L}^{-1}\right)$ : Lactose, 5.0; beef extract, 3.0; peptone, 5.0; Agar, 15.0 with pH-7.0. After $48 \mathrm{~h}$ of incubation period, blue colored colonies were examined. Selected isolates were stored on lactose medium slant and in $40 \%$ glycerol for short and long term preservation, respectively. The purified bacterial strains were screened for $\beta$-galactosidase production by growing on lactose agar medium (supplemented with $\mathrm{X}$-gal and IPTG) at $37^{\circ} \mathrm{C}$ for $48 \mathrm{~h}$ (Jaturapiree et al., 2012). Among them, blue colored colonies of Bacillus strain B-2 were prominently observed on lactose agar medium that indicates the production of $\beta$-galactosidase into medium after cleaving the chromogenic substrate (X-gal) which was supplemented with lactose into culture medium plate. But in our study, we had developed a novel quantitative method to screen the isolates on $\beta$-galactosidase production using spectrophotometry method in X-Gal and IPTG solution.

\section{Purification of $\beta$-galactosidase enzyme}

Purification of $\beta$-galactosidase enzyme was carried out employing various t-butanol ratios (crude extract: t-butanol $=1: 0.25,1.0: 0.5$, 1.0:1.0, 1.0:1.5, 1.0:2.0) with a different ammonium sulfate saturation at 30,60 and $90 \%$. The mixture was mixed gently and then allowed to stand for $30 \mathrm{~min}$ at $37^{\circ} \mathrm{C}$. afterward, the mixture was centrifuged at $5000 \mathrm{rpm}$ for 15 $\min$ at $4^{\circ} \mathrm{C}$ to facilitate the separation of phases. The upper t-butanol phase was removed by the Pasteur pipette. The lower aqueous phase and the interfacial phase were separated carefully and each of phases was analyzed for enzyme activity. Different ammonium sulfate saturation effects (30, 60 and 90\%) (w/v) were investigated at the best recovery activity of crude enzyme: t-butanol ratio that is 1.0:1.0. The bottom phase and interfacial phase were analyzed for enzyme activity (Duman and Kaya, 2013). The enzyme assay evaluates the $\beta$ galactosidase enzyme, which was present in selected Lactobacillus cultures. Lactobacillus cultures i.e. V3, NK2 and NK9 were statistically analysed for the different ammonium sulphate saturation effects, different sample size of crude enzyme: t-butanol ratio and highest production of $\beta$-galactosidase enzyme. $\beta$-galactosidase enzyme production of Lactobacillus cultures i.e. V3, NK2 and NK9 were presented in figure 10 . In figure $10, \beta-$ galactosidase activity of $\mathrm{V} 3$ culture was significantly $(\mathrm{P}<0.05)$ increased at $60 \%$ ammonium sulphate saturation and ratio of crude enzyme: t-butanol $(1: 1 ; 2 \%) . \quad \beta$ galactosidase activity was significantly highest at $60 \%$ ammonium sulphate saturation for all the three Lactobacillus cultures (V3, NK2 and NK9) followed by 30 and $90 \%$. Significantly maximum $\beta$-galactosidase production was also observed at $60 \%$ ammonium sulphate saturation in case of V3 culture (0.377O.D), followed by NK9 (0.283 O.D) and NK2 (0.216 O.D) compared to $30 \%$ ammonium sulphate saturation of V3 (0.287 O.D) followed by NK9 $\left(\begin{array}{llll}0.246 & \text { O.D) and NK2 (0.186 O.D) and }\end{array}\right.$ subsequently also compared with $90 \%$ ammonium sulphate saturation for NK9 $(0.248$ 
O.D), followed by V3 (0.238 O.D) and NK2 (0.172 O.D).From figure 10, it was observed that the $\beta$-galactosidase activity of $\mathrm{V} 3, \mathrm{NK} 2$ and NK9 cultures were significantly $(\mathrm{P}<0.05)$ increased with the different ammonium sulphate saturations (30 and $60 \%$ ) and various crude enzyme:t-butanol ratios $(1: 0.25 ; 1.25,1: 0.5 ; 1.5$ and $1: 1 ; 2)$ during purification process. But $\beta$ galactosidase activity were significantly decreased at ammonium sulphate saturation effect $(90 \%)$ and various crude enzyme: tbutanol ratios $(1: 1.5 ; 2.5$ and $1: 2: 3 \%)$. Significantly maximum $\beta$-galactosidase activity was observed at $(1: 1: 2 \%)$ crude enzyme: $t$ butanol ratio (0.353 O.D), followed by $1: 1.5$; $2.5 \%$ (0.274 O.D), 1:2:3\% (0.236 O.D), 1:0.5; $1.5 \%$ (0.228 O.D) and $1: 0.25 ; 1.25 \%(0.159$ O.D) during purification process.

Prasad et al., (2013) evaluated that the production of $\beta$-galactosidase by Bifidobacterium animalis ssp. lactis Bb12 and Lactobacillus delbrueckii ssp. bulgaricus ATCC 11842 in whey and the effect of 4 different extraction methods i.e. sonication, acetone-toluene, SDS-chloroform and lysozyme-EDTA treatment on enzyme activity from these organisms. Both organisms were grown in deproteinised whey containing yeast extract $(3.0 \mathrm{~g} / \mathrm{L})$, peptone $(5.0 \mathrm{~g} / \mathrm{L})$ and glucose $(10.0 \mathrm{~g} / \mathrm{L})$ for $18 \mathrm{~h}$, at $37^{\circ} \mathrm{C}$ for B. animalis ssp. lactis $\mathrm{Bb} 12$ and at $45^{\circ} \mathrm{C}$ for L. delbrueckii ssp. bulgaricus ATCC 11842. The optimum intracelluar $\beta$-galactosidase activity on $15 \mathrm{mM}$ o-nitrophenyl $\beta$-D-galactopyranoside (ONPG) assay was at $\mathrm{pH} 6.8$ for both organisms irrespective of the method of extraction used. Also, the effect of temperature on enzyme activity was studied at various temperatures (30, $35,40,45$ and $50^{\circ} \mathrm{C}$ ). At $35^{\circ} \mathrm{C}$ and $40^{\circ} \mathrm{C}, B$. animalis ssp. lactis $\mathrm{Bb} 12$ evaluated more intracellular $\beta$-galactosidase activity extracted by sonication than other temperatures and methods. However, L. delbrueckii ssp. bulgaricus ATCC 11842 had more intracellular $\beta$-gal activity at $35^{\circ} \mathrm{C}$ and $45^{\circ} \mathrm{C}$ when extracted by lysozyme-EDTA treatment. Among the four methods used for $\beta$-galactosidase extraction, sonication exhibited the best result $(6.80$
Unit $/ \mathrm{mL}$ ) for B. animalis ssp. lactis $\mathrm{Bb} 12$ while lysozyme-EDTA treatment was also found to be the best (7.77 Unit/ $\mathrm{mL})$ for L. delbrueckii ssp. bulgaricus ATCC 11842. These treatments are similar as our study. Duman and Kaya, (2013) evaluated the activity of $\beta$-galactosidase was completely decreased at $60 \%$ ammonium sulfate saturation in aqueous phase, the best results of recovery and the purification fold of $\beta$-galactosidase (133\% and 10.1, respectively) was obtained in the interfacial phase. Probably, this saturation was caused by the precipitation of whole target protein molecule in the interfacial phase. Generally, researchers started with minimum salt concentration of $20 \%(\mathrm{w} / \mathrm{v})$ to optimize the partitioning conditions (Dennison et al., 1997). In that study also evaluated the minimum salt saturations for the beginning and the increasing of salt concentrations resulted with the increasing of recovery and purification fold in the interphase up to $60 \%(\mathrm{w} / \mathrm{v})$ saturations. Higher salt concentrations from this point were resulted with reducing of recovery and purification fold, which may be due to irreversible denaturation of protein (Narayan et al., 2008). This results obtained as similar data found in our study.

\section{Purification of $\beta$-galactosidase enzyme through SDS-PAGE}

$\beta$-galactosidase enzyme extracts from different Lactobacillus cultures were subjected to SDSPAGE analysis along with Bovine serum albumin (BSA- $66.2 \mathrm{kDa}$ ) as a marker (Fig. 11). The molecular mass of partially purified $\beta$ galactosidase $(60 \%$ Ammonium sulphate saturation) from selected Lactobacillus cultures i.e. V3, NK2 and NK9 as determined by SDSPAGE was approx. $69 \mathrm{kDa}$ (Fig. 11). Presence of high molecular weight protein band nearer to BSA in LAB showed Mol. Weight of $\beta$ galactosidase. The protein band of $62 \mathrm{kDa}$ corresponds to $\beta$-galactosidase enzyme as reported by previous workers (Pal et al., 2013). These results raised the expectation of finding $\beta$-galactosidase enzyme in LAB. Out of ten Lactobacillus cultures, three cultures i.e. V3, NK2 and NK9 showed highest production of $\beta$ - 
galactosidase after $24 \mathrm{~h}$ at $37^{\circ} \mathrm{C}$. Sonication treatment was also found best for the maximum production of $\beta$-galactosidase under the optimized growth condition. $60 \%$ Ammonium sulphate and crude enzyme:t-butanol=1:1 also produced maximum partially purified $\beta$ galactosidase enzyme for further study. These three Lactobacillus cultures could be used as $\beta$ galactosidase producer.

\section{Conflicts of interest}

There is no conflict of interest in the study among the authors.

\section{Authors' contributions}

All the authors contributed equally to the writing of this paper. They were also involved in the overall work of experiments.

\section{References}

Antunes A. E. C., Cazetto T. F. and Bolini H. M. A., Viability of probiotic microorganisms during storage, post acidification and Fig. 12 MS/MS spectrum of fraction E1 inspected in MASCOT database (Identified 'ETVPYMFEN' amino acid sequence as 'lactoferrin')sensory analysis of fat-free yoghurts with added whey protein concentrate, International Journal of Dairy Technology, 58,169-173 (2005).

Berni Canani R., Pezzella V., Amoroso A. et al., Diagnosing and treating intolerance to carbohydrates in children, Nutrients, 8 , 155-157 (2016).

Bury, T. and Jelen, P., Lactose hydrolysis in milk as affected by neutralizers used for the preparation of crude $\beta$-galactosidase extracts from Lactobacillus bulgaricus 11842, Innovative Food Science and Emerging Technologies, 3, 175-188 (2001).

Burya D., Jelena P., Kimura K., Whey protein concentrateas a nutrient supplement for lactic acid bacteria, International Dairy Journal, 8,149-151 (1998).

Carrasco-Castilla J., Hernandez A., Lvarez A. J. et al., Antioxidant and metal chelating activities of Phaseolus vulgaris $\mathrm{L}$. var. Jamapa protein isolaes, phaseolin and lectin hydrolysates. Food chemistry, 131, 1157-1164 (2012).

Deng Y., Misselwitz B., Dai N. and Fox M., Lactose intolerance in adults: biological mechanism and dietary management, Nutrients, $\quad 7, \quad 8020-8035$ (2015)

Dennison C. and Lovrein R., Three phase partitioning: concentration and purification of proteins, Protein Expression and Purification, 11, 149-161 (1997)

Duman Y. and Kaya E. Purification, recovery, and characterization of chick pea (Cicer arietinum) b-galactosidase in single step by three phase partitioning as a rapid and easy technique, Journal of Dairy Science, 91, 155-160 (2013)

Hati S., Patel N., Sakure A. and Mandal S. Influence of whey protein concentrate on the production of antibacterial peptides derived from fermented milk by lacticacid bacteria, International Journal of Peptide Research and Therapeutics, (2017)

Hati S., Sreeja V., Solank, J. and Prajapati J. B. Significance of proteolytic microorganisms on ACE-inhibitory activity and release of bioactive peptides during fermentation of milk, Indian Journal of Dairy Science, 68, 584-591 (2015)

IDF 146, Yogurt-Identification of characteristic microorganisms (Lactobacillus delbrueckii subsp. bulgaricus and Streptococcus thermophilus), International Standard, (2003)

Indian Standards., Methods of test for dairy industry part-Irapid examination of milk, Indian Standards Institution, New Delhi (1479) (1960)

Jaturapiree P., Phuengjayaeam S., Seangsawang S. et al., Isolation and production of novel $\beta$-galactosidase from a newly isolated, moderate thermophile, Bacillus sp. strain B1, Journal of Food Science and Engineering, 2, 395-402 (2012) 
Jelen P., Lactose hydrolysis using sonicated dairy cultures, In Lactose hydrolysis, IDF Brussels Belgium Bulletin, 289, 54-56 (1993)

Kamran A., Bibi Z., and Aman A. et al., Lactose hydrolysis approach: Isolation and production of $\beta$-galactosidase from newly isolated Bacillus strain B-2, Biocatalysis and Agricultural Biotechnology, 5, 99-103 (2016)

Kara F., Release and characterization of betagalactosidase from Lactobacillus plantarum, Biotechnology, METU (2004).

Laemmli U. K., Cleavage of structural proteins during assembly of the head of bacteriophage T4, Nature, 227, 680-685 (1970)

Milanovic S., Ilicic M., Duric M., Caric M., Effect of transglutaminase and whey protein concentrate on textural characteristicsof low fat probiotic yoghurt, Milchwissenschaft, 64, 388-392 (2009)

Narayan A. V., Madhusudhan M. C. and Raghavarao S. M., Extraction and purification of ipomea peroxidase employing three-phase partitioning, Applied Biochemistry and Biotechnology, 151, 263-272 (2008)

NIDDK, Lactose Intolerance, National Institute of Diabetes and Digestive and Kidney Diseases (NIDDK), pp: 12-16 (2016)
Pal A., Lobo M. and Khanum F., Extraction, purification and thermodynamic characterization of almond (Amygdalus communis) $\beta$-galactosidase for the preparation of delactosed milk, Food Technology and Biotechnology, 51, 53-61 (2013)

Prasad L. N., Ghosh B. C., Sherkat F. et al., Extraction and characterisation of $\beta$ galactosidase produced by Bifidobacterium animalis spp. lactis Bb12 and Lactobacillus delbrueckii spp. bulgaricus ATCC 11842 grown in whey, International Food Research Journal, 20, 487-494 (2013)

Skovbjerg H., Sjostrom H. and Noren O., Purification and characterization of amphiphilic lactase/phlorizin hydrolase from human small intestine, European Journal of Biochemistry, 114, 653-661 (1981)

Vasiljevic T. and Jelen P., Production of $\beta$ galactosidase for lactose hydrolysis in milk and dairy products using thermophilic lactic acid bacteria, Innovative Food Science and Emerging Technologies, 2, 75-85 (2001)

Vikas S., Sudhir K., Tomar B. A., Ram R. B. and Ashish K. S. Production of $\beta$ galactosidase from Streptococcus thermophilus for galactooligosaccharides synthesis, Journal of Food Science and Technology, 52, 4206-4215 (2015)

\section{How to cite this article:}

Shrushti Makwana, Subrota Hati, Heena Parmar and Aparnathi, K.D. 2017. Process Optimization for the Production of $\beta$-Galactosidase Using Potential Lactobacillus Cultures. Int.J.Curr.Microbiol.App.Sci. 6(8): 1454-1469. doi: https://doi.org/10.20546/ijcmas.2017.608.176 